\title{
Effects of microbial inoculants and amino acid production by-product on fermentation and chemical composition of sugarcane silages
}

\section{Paulo Henrique Mazza Rodrigues ${ }^{1,2}$, Rodrigo da Costa Gomes ${ }^{3}$, Paula Marques Meyer ${ }^{4}$, Laura Maria Oliveira Borgatti ${ }^{1}$, Fernando Masello Junqueira Franco ${ }^{5}$, Gilson Luiz Alves de Godoy ${ }^{1}$}

\footnotetext{
${ }^{1}$ Departamento de Produção e Nutrição Animal, FMVZ/USP, Av. Duque de Caxias Norte, 225, 13635-900, Pirassununga-SP, Brasil.

2 Research Productivity fellow at CNPq.

${ }^{3}$ Departamento de Zootecnia, FZEA/USP, Av. Duque de Caxias Norte, 225, 13635-900, Pirassununga, SP, Brasil.

${ }^{4}$ Instituto Brasileiro de Geografia e Estatística (IBGE). Rua Duque de Caxias, 1332, $2^{\circ}$ andar, Centro, 13630-095, Pirassununga - SP Brasil.

${ }^{5}$ Centro de Planejamento e Desenvolvimento da Ajinomoto do Brasil.
}

\begin{abstract}
The objective of this study was to evaluate the chemical composition, fermentation patterns and aerobic stability of sugarcane silages with addition of amino acid production (monosodium glutamate) by-product (APB) and microbial inoculants. Mature sugarcane was chopped and ensiled in laboratory silos $(n=4 /$ treatment $)$ without additives (control) and with APB $(10 \mathrm{~g} / \mathrm{kg})$, Pioneer $1174{ }^{\circledR}$ (PIO, $1.0 \mathrm{mg} / \mathrm{kg}$, Lactobacillus plantarum + Streptoccoccus faecium, Pioneer), Lalsil Cana $\left(2.0 \mathrm{mg} / \mathrm{kg}\right.$, Lactobacillus buchineri, Lallemand) or Mercosil Maís $11 \mathrm{C} 33^{\circledR}(1.0 \mathrm{mg} / \mathrm{kg}$, Lactobacillus buchineri + Lactobacillus plantarum + Streptoccoccus faecium, Timac Agro). Fresh silage and silage liquor samples were obtained to assess $\mathrm{pH}$, chemical composition and organic acid concentrations. Silage temperature was recorded throughout seven days to evaluate aerobic stability. The addition of APB decreased lactic acid levels, increased $\mathrm{pH}$ and $\mathrm{N}-\mathrm{NH}_{3}$ and did not alter ethanol, acetic and butyric acids concentrations or dry matter (DM) losses. Microbial inoculants enhanced acetic acid levels, although only Pioneer $1174^{\circledR}$ and Mercosil Maís $11 \mathrm{C} 33^{\circledR}$ lowered ethanol, butyric acid and DM losses. The addition of APB increased CP content and did not modify DM, soluble carbohydrates contents or in vitro dry matter digestibility. Additives did not alter silage maximum temperature or temperature increasing rate; however, Pioneer $1174^{\circledR}$ and Mercosil Maís $11 \mathrm{C} 33^{\circledR}$ increased the time elapsed to reach maximum temperature. Monosodium glutamate production by-product does not alter fermentation patterns or aerobic stability of sugarcane silages, whereas homofermentative bacteria can provide silages of good quality.
\end{abstract}

Key Words: aerobic stability, ammonia, ethanol, lactic acid bacteria, Saccharum officinarum L.

\section{Introduction}

Alcoholic fermentation represents one of the most important problems for sugarcane ensiling, which requires methodologies to assure low ethanol production during fermentation. With this aim, microbial inoculants and other products have been added to forages during ensiling, in order to decrease fungi and yeast growth. Fungi and yeast have high activity in the sugarcane fermentation, converting simple sugars into ethanol, carbon dioxide and water, with forage quality and dry matter losses as a consequence (Alli et al., 1982).

Homofermentative and heterofermentative bacteria, such as Lactobacillus plantarum, Lactobacillus buchneri and Streptoccoccus faecium, have demonstrated this capacity when ensiling other forages, whether by the production of compounds that inhibit the growth of some microorganisms (Niku-Paavola et al., 1999), by the rapid growth in aerobiosis (Weinberg \& Muck, 1996) and resulting competition with yeast, or by the conversion of lactic acid into acetic and propionic acids (Elferink et al., 2001), which are strong antifungic (Moon, 1983). Similarly, nitrogen sources such as urea and ammonium sulfate may decrease ethanol production in sugarcane silages. These additives can inhibit yeast growth (Bravo-Martins et al., 2006) because the ammonia that was produced by their hydrolysis would be toxic to yeast and fungi (Alli et al., 1983).

The by-product derived from the monosodium glutamate production (APB) has not been tested as additive for ensiled forages yet, although it is rich in nitrogen. The APB has been evaluated as a nitrogen source for ruminants and demonstrated to significantly increase rumen ammonia concentration (Macitelli et al., 2003). Therefore, it is likely that the addition of APB in the sugarcane ensiling will 
increase the ammonia nitrogen content of the ensiled mass, contributing to inhibit the growth of yeast and fungi and, consequently, to diminish the ethanol production.

Thus, the objective of this study was to evaluate the chemical composition and the fermentative patterns of sugarcane silage with the addition of monosodium glutamate by-product and microbial additives.

\section{Material and Methods}

The study was carried out at the Department of Animal Nutrition and Production, in the College of Veterinary and Animal Science of Universidade de São Paulo. Mature sugarcane (Saccharum officinarum L.) was harvested and chopped to particles of $0.98-\mathrm{cm}$ (Table 1 ). The experimental design was completely randomized, with four treatments and four replicates per treatment, which were: control (untreated silage); $1 \%$ APB in the ensiled mass (as is) (APB); treatment with Pioneer $1174^{\circledR}$ (Pioneer); treatment with Lalsil Cana (Lallemand AS) or treatment with Mercosil Maís $11 \mathrm{C} 33^{\circledR}$ (Timac Agro).

Microbial additives were previously diluted in distilled water according to the manufacturer guidelines. Pioneer $1174{ }^{\circledR}$ contained Streptococcus faecium and Lactobacillus plantarum, at $1.0 \times 10^{11} \mathrm{cfu} / \mathrm{g}$ and was applied to the fresh forage at $1.0 \mathrm{mg} / \mathrm{kg}$ (as is). Lalsil Cana contained Lactobacillus buchneri at $2.5 \times 10^{10} \mathrm{cfu} / \mathrm{g}$ and was applied at $2.0 \mathrm{mg} / \mathrm{kg}$ of fresh forage. Mercosil Maís $11 \mathrm{C} 33^{\circledR}$ contained Lactobacillus buchneri $\left(1.0 \times 10^{11} \mathrm{cfu} / \mathrm{g}\right)$, Lactobacillus plantarum $\left(8.0 \times 10^{9} \mathrm{cfu} / \mathrm{g}\right)$ and Streptococcus faecium $\left(2.0 \times 10^{9} \mathrm{cfu} / \mathrm{g}\right)$ and was applied at $1.0 \mathrm{mg} / \mathrm{kg}$ of fresh forage.

The inoculants were applied with a sprayer while the forage was mixed manually. Ensiling was performed immediately after applying the additives. Twenty 6-liter polypropylen tubes were used as laboratory silos. The forage was put in tubes and compacted tightly, and then tubes were sealed and weighed. Compaction was carried out to exceed a density of $500 \mathrm{~kg}$ of fresh forage $/ \mathrm{m}^{3}$. Silos were kept in vertical position in a sheltered barn and open following 61 days of storage.

Before opening, silos were weighed to determine the dry matter losses. Fermentation losses were calculated as the difference between the initial and the final weight of each silo multiplied by the dry matter content of the ensiled mass. The dry matter losses were converted to percentage of the initial weight.

All chemical analyzes were carried out at the Laboratory of Animal Nutrition and Chemical Analysis of the Department of Animal Nutrition and Production (College of Veterinary and Animal Science of Universidade de São Paulo). After the silos were opened, silage was homogenized and a sample was obtained to determine the silage chemical composition. Dry matter content was determined after drying in forced-ventilation oven $\left(55^{\circ} \mathrm{C}, 72 \mathrm{~h}\right)$ and sterilization oven $\left(105^{\circ} \mathrm{C}, 24 \mathrm{~h}\right)$. Crude protein content was determined according to AOAC (1980); neutral and acid detergent fiber and acid detergent lignin, according to Van Soest et al. (1991); soluble carbohydrates, according to Johnson et al. (1966) and acid detergent insoluble nitrogen, according to Van Soest \& Robertson (1985).

Another silage sample was pressed in a manual screw to extract the juice. Silage $\mathrm{pH}$ was measured in $50 \mathrm{~mL}$ silage juice using a digital $\mathrm{pH}$ meter (Procyon, model 310), that had been previously calibrated for buffer solutions with $\mathrm{pH}$ of 4.0 and 7.0 .

To quantify the concentration of organic acids and ethanol, 1 -mL of silage juice was mixed with $0.2 \mathrm{~mL}$ formic acid in ambar glass bottles and immediately frozen $\left(-18^{\circ} \mathrm{C}\right)$ until analyses. Concentrations of acetic, propionic and butiric acids and of ethanol were measured by gas chromatography, according to Erwin et al. (1961), using a Thermo Scientific ${ }^{\circledR}$ chromatograph (Focus GC, Thermo Fusher Scientific Inc., Waltham, MA, USA) with an automatic sample injection (Thermo Electron Corporation ${ }^{\circledR}$, model AS-3000), a glasspacked column $\left(2.0 \mathrm{~m} \times 1 / 5 ", 80 / 120\right.$ Carbopack $^{\circledR} \mathrm{B}-\mathrm{DA} / 4 \%$ Carbowax ${ }^{\circledR} 20 \mathrm{M}$ phase) and flame ionization detector (FID) set at $270^{\circ} \mathrm{C}$. Temperatures of the chromatograph oven and injector were set to $190^{\circ} \mathrm{C}$ and $220^{\circ} \mathrm{C}$, respectively, during analyses and high-purity hydrogen was used as drag gas at flow rate of $30 \mathrm{~mL} / \mathrm{min}$. The number of replicates was that needed for differences across readings below $5 \%$.

The acid lactic concentration was determined by high performance liquid chromatography (HPLC), according to Ding et al. (1995), using a LC-10ADVP Shimadzu HPLC system (Shimadzu Inc., Kyoto, Japan), composed of automatic injector, moving phase pump, column oven,

Table 1 - Chemical composition of ingredients of sugarcane and amino acid production by-product (APB)

\begin{tabular}{lcccccccc}
\hline Ingredient & DM & CP & ADIN & ADF & NDF & SC & IVDMD \\
\hline Sugarcane & 281 & 29 & 387 & 372 & 563 & 362 & 503 & 5.3 \\
APB & 552 & 807 & 0 & 0 & 0 & 0 & - & 83.9 \\
\hline
\end{tabular}

DM - dry matter ( $\mathrm{g} / \mathrm{kg})$; CP - crude protein $(\mathrm{g} / \mathrm{kg}$ DM); ADIN - acid detergent insoluble nitrogen $(\mathrm{N})(\mathrm{g} / \mathrm{kg}$ of total N); ADF - acid detergent fiber ( $\mathrm{g} / \mathrm{kg}$ DM); NDF - neutra detergent fiber (g/kg DM); SC - soluble carbohydrates (g/kg DM); IVDMD - in vitro dry matter digestibility ( $/ \mathrm{kg} \mathrm{DM}$ ); BC - buffer capacity (meq./100 g DM). 
UV-VIS detector and a control system connected to a microcomputer. The HPLC included a $\mathrm{C}_{18}$-ODS column $(15 \mathrm{~cm} / 0.6 \mathrm{~cm}, 5 \mu \mathrm{m}, 100 \AA)$. The oven temperature was set to $50{ }^{\circ} \mathrm{C}$, the flux of $\mathrm{H}_{2} \mathrm{SO}_{4}(0.75 \mathrm{mM}$, degased with highpurity helium) was set to $1.0 \mathrm{~mL} / \mathrm{min}$ and the UV-VIS detector to $210 \mathrm{~nm}$. Calibration was performed by injecting $2.0 \mu \mathrm{L}$ mixed standard solution containing lactic acid and using a standard curve in the SHIMADZU CLASS-VP v.5.031 software. The number of replicates was that needed for differences across readings below $5 \%$.

Two-milliliter juice samples were put in glass tubes with $1 \mathrm{~mL} 1 \mathrm{~N} \mathrm{H}_{2} \mathrm{SO}_{4}$ and frozen until analyses. Ammonia nitrogen $\left(\mathrm{N}-\mathrm{NH}_{3}\right)$ concentration was determined in theses samples by colorimetry, according to Kulasek (1972) and adaptations by Foldager (1977). The absorbance readings were carried out in spectrophotometer set at $630 \mathrm{~nm}$. Absorbance values were used to calculate the $\mathrm{N}-\mathrm{NH}_{3} / 100 \mathrm{~mL}$, through linear regression using a standard curve.

In vitro dry matter digestibility (IVDMD) was measured according to Tilley \& Terry (1963). Briefly, $0.5 \mathrm{~g}$ of dried samples were weighed in centrifuge tubes with $40 \mathrm{~mL}$ McDougall solution and $10 \mathrm{~mL}$ rumen liquid that had been obtained from grazing cows (Brachiaria spp.), supplemented with chopped sugarcane and mineral mixture. Each tube was flushed with $\mathrm{CO}_{2}$, capped and incubated for $48 \mathrm{~h}$ in an oven set to $39{ }^{\circ} \mathrm{C}$. The tubes were shaken two to three times during the incubation period. After incubation, the tubes were centrifuged and the supernatant was discarded. Fifty milliliters of pepsin solution $(1: 10.000)$ were added to each tube, and a new 48-hour period of incubation was allowed. The residual mass after fermentation was dried and weighed to determine the IVDMD.

A $3.0 \mathrm{~kg}$ fresh silage sample was obtained from each replicate, put in Styrofoam container (2 L) and kept in room temperature $\left(25^{\circ} \mathrm{C}\right)$. Temperatures of the samples were measured every $30 \mathrm{~min}$, for 7 days, using a data acquisition system composed of 12 thermocouples probes, two data acquisition panels, and a software for monitoring, acquisition and control of environmental variables (MACVA, v.1.2). The maximum temperature reached $\left({ }^{\circ} \mathrm{C}\right)$, the time spent to reach the maximum temperature $(\mathrm{h})$ and the time spent to increase $2{ }^{\circ} \mathrm{C}(\mathrm{h})$ were measured. Aerobic stability was calculated as the temperature increasing rate, dividing the maximum temperature reached by the time spent to reach it (Ruppel et al., 1995).

The software SAS (Statistical Analysis System, version 9.1) was used for data analyses. The data were tested for normality of residues using the Shapiro-Wilk test (Proc Univariate) and transformed into $\log (\mathrm{x}+1)$ or $\mathrm{RQ}(\mathrm{x}+1 / 2)$ when needed. The original and the transformed data were submitted to one-way ANOVA (Proc GLM) and means were separated by Tukey test. The significance level adopted was $5 \%$.

\section{Results and Discussion}

The chemical composition of the sugarcane was similar to that commonly found in the literature (Table 1). Low CP $(2.9 \%)$ and high acid detergent insoluble nitrogen (ADIN; $38.7 \%$ ) contents illustrate the need for nitrogen supplementation when this forage is used as the single feed in diets for ruminants and justify the evaluation of nitrogen sources, such as the APB, as additives to complement the nutrition value of the sugarcane. The low $\mathrm{CP}$ and high soluble carbohydrate (SC) contents indicate high degree of maturation of the harvested plant.

The APB presented high CP content $(807 \mathrm{~g} / \mathrm{kg} \mathrm{DM})$ and moderate humidity level (552 g/kg fresh matter). In a study where a similar product was included in diets for cattle (Macitelli et al., 2003), lower DM and CP contents were observed (420 and $625 \mathrm{~g} / \mathrm{kg} \mathrm{DM}$ ). In this case, authors reported that the product contained $200 \mathrm{~g} \mathrm{~N}-\mathrm{NH}_{3} /$ total $\mathrm{N}$; therefore, the product increased rumen $\mathrm{NH}_{3}$ when included in the diet. A similar effect was expected in the silage that contained APB.

Untreated silage (control) had low quality, as it presented alcoholic fermentation (137 g ethanol/kg DM) (Table 2). Furthermore, the silage presented other undesirable characteristics such as acetic acid concentration above $20 \mathrm{~g} / \mathrm{kg}$ DM and lactic to acetic ratio below 3.0, although the butiric acid concentration (below $2 \mathrm{~g} / \mathrm{kg} \mathrm{DM}$ ) and the $\mathrm{pH}$ (below 4.0) were adequate. These results agree with the alcoholic fermentation that is typical in sugarcane silages.

With respect to the effects of treatments with additives on fermentation (Table 2), Pioneer and Mercosil inoculants reduced the ethanol concentration in $85.4 \%$ and $84.7 \%$ $(\mathrm{P}<0.05)$, increased acetic acid concentration in $191.6 \%$ and $164.4 \%(\mathrm{P}<0.05)$ and reduced butiric acid concentration in $61.5 \%$ and $53.8 \%$, respectively, in comparison with the untreated silage. These changes resulted in a decrease in the lactic to acetic ratio of $64.0 \%$ and $57.6 \%(\mathrm{P}<0.05)$, a drop of the $\mathrm{pH}$ of $7.6 \%$ and $6.7 \%(\mathrm{P}<0.05)$ and a reduction in $\mathrm{DM}$ losses of $39.8 \%$ and $47.6 \%$, respectively. In turn, Lalsil increased acetic acid concentration (86.2\%), did not control the production of butiric acid (increment of $38.5 \%$ ) and did not affect the concentrations of ethanol and lactic acid or DM losses.

The inoculants tested in the present study were capable to modify the fermentation pattern in the sugarcane ensiling. Pioneer and Mercosil contained both the bacteria 
Table 2 - Fermentation patterns and dry matter (DM) losses of sugarcane silages untreated and treated with additives

\begin{tabular}{|c|c|c|c|c|c|c|c|}
\hline \multirow[t]{2}{*}{ Item } & \multicolumn{5}{|c|}{ Treatment $^{1}$} & \multirow[b]{2}{*}{$\mathrm{CV}$} & \multirow[b]{2}{*}{$\operatorname{Pr}>F$} \\
\hline & Control & $\mathrm{APB}$ & Pioneer & Lalsil & Mercosil & & \\
\hline Ethanol & $13.73 \mathrm{a}$ & $17.24 \mathrm{a}$ & $2.01 \mathrm{~b}$ & $14.17 \mathrm{a}$ & $2.10 \mathrm{~b}$ & 77.90 & 0.0002 \\
\hline Acetic & $2.39 \mathrm{c}$ & $1.88 \mathrm{c}$ & $6.97 \mathrm{a}$ & $4.45 b$ & $6.32 \mathrm{a}$ & 48.46 & 0.0001 \\
\hline Propionic acid & 0.014 & 0.011 & 0.006 & 0.010 & 0.006 & 73.88 & 0.5578 \\
\hline Butiric acid & $0.065 \mathrm{~b}$ & $0.069 \mathrm{ab}$ & $0.025 \mathrm{c}$ & $0.090 \mathrm{a}$ & $0.030 \mathrm{c}$ & 49.01 & 0.0001 \\
\hline Lactic acid & $3.28 \mathrm{a}$ & $2.77 \mathrm{~b}$ & $3.47 \mathrm{a}$ & $3.22 \mathrm{ab}$ & $3.68 \mathrm{a}$ & 11.46 & 0.0009 \\
\hline Lactic:acetic & $1.39 \mathrm{a}$ & $1.47 \mathrm{a}$ & $0.50 \mathrm{~b}$ & $0.73 b$ & $0.59 \mathrm{~b}$ & 46.42 & 0.0001 \\
\hline $\mathrm{pH}$ & $3.30 \mathrm{~b}$ & $3.43 \mathrm{a}$ & $3.05 \mathrm{c}$ & $3.28 b$ & $3.08 \mathrm{c}$ & 4.76 & 0.0001 \\
\hline $\mathrm{N}-\mathrm{NH} 3$ & $12.63 b$ & $26.19 \mathrm{a}$ & $11.57 \mathrm{~b}$ & $11.95 b$ & $10.82 b$ & 39.80 & 0.0001 \\
\hline DM losses & $21.20 \mathrm{ab}$ & $22.46 \mathrm{a}$ & $12.77 \mathrm{ab}$ & $20.93 \mathrm{ab}$ & $11.10 \mathrm{~b}$ & 37.99 & 0.0178 \\
\hline
\end{tabular}

${ }^{1}$ Means in the same row followed by different letters differ by the Tukey test $(\mathrm{P}<0.05)$.

Ethanol (\% DM); Acetic (\% DM); Propionic (\% DM); Butiric (\% DM); Lactic (\% DM); Lactic:Acetic - lactic:acetic acid ratio; N-NH 3 - ammonia nitrogen (\% of total N); $\mathrm{DM}$ losses (\% DM); CV - coefficient of variation (\%); $\mathrm{Pr}>\mathrm{F}$ - probability of type I error.

Lactobacillus plantarum and Streptoccoccus faecium. Lactobacillus plantarum is a homofermentative bacterium that produces bactericins and low molecular weight compounds that inhibit the growth of bacteria, yeast and fungi (Niku-Paavola et al., 1999). The Streptococcus faecium (or Enterococcus faecium) is homofermentative as well; however, it grows fast in aerobic conditions, in the initial steps of the ensiling process, and has been related to desirable fermentation when combined with Lactobacillus (Weinberg \& Muck, 1996). On the other hand, Lalsil Cana contained Lactobacillus buchineri, which is heterofermentative and capable to use lactic acid in nontoxic and low $\mathrm{pH}$ environments $(<5.8)$ to convert it into acetic acid (Elferink et al., 2001).

According to some authors (Kung et al., 1991; Weinberg et al., 1993), the inoculation of homofermentative bacteria such as those contained in Pioneer and Mercosil, may not avoid the growth of aerobic yeast and fungi. Production of antifungic by homofermentative bacteria would be low because the inhibitory capacity of lactic acid is lower than that of acetic acid and, especially, of propionic acid (Moon, 1983, Ranjit \& Kung Jr., 2000). It is noteworthy that the inoculants did not alter lactic acid production. Instead, heterolactic bacteria, such as Lactobacillus buchineri, would present the advantage of improving antifungal strength of silage due to the greater release of acetic acid (Ranjit \& Kung Jr., 2000).

Due to the differences of the metabolism products between homo and heterofermentative bacteria, it was expected that both Lalsil Cana and Mercosil, which contained Lactobacillus buchineri, would increase the acetic acid concentration and diminish ethanol production. Nevertheless, the present results showed that Lalsil Cana did not modify the silage ethanol concentration, although it increased acetic acid production. An explanation for this fact would be that the amount of acetic acid may have been low and not enough to inhibit ethanol production, since the increment of acetic acid production was lower than that occurring for the two other inoculants. Mercosil provided Lactobacillus plantarum and Streptococcus faecium, in addition to Lactobacillus buchineri. These microorganisms were also present in Pioneer, which provided desirable fermentation, with marked reduction of ethanol concentration. Consequently, these results suggest that in the present study the fermentation profile of sugarcane silage was more consistently altered by homofermentative bacteria than by heterofermentative bacterium Lactobacillus buchineri.

These results differ from those found by Castro Neto et al. (2008), who evaluated the inoculation of sugarcane silage with Lactobacillus plantarum (Biomax 5) and observed no effects on $\mathrm{DM}, \mathrm{NH}_{3}$ /total $\mathrm{N}$ and soluble carbohydrates content, as well as no effects on lactic, acetic and butyric acids and ethanol. According to the authors, the reason for this result may have been the reduced or similar growth rate of the inoculated microorganisms in comparison with that of the native silage microbial population. It is likely that the same may have occurred for the heterolactic bacteria of Lalsil Cana, in the present study.

The increase in the acetic acid concentration in sugarcane silage with the inoculation of homolactic bacteria was lower than that observed for the inoculation with Lactobacillus buchneri. Nevertheless, the former promoted a much greater decrease of ethanol production when compared with the latter. Thus, the results suggest that antifungic agents other than acetic and propionic acids may have been produced by bacteria from Pioneer and Mercosil.

The only effects of the by-product of amino acid production (APB) were a decrease of the lactic acid concentration of $15.5 \%(\mathrm{P}<0.05)$, an increase of the $\mathrm{pH}$ in $3.9 \%(\mathrm{P}<0.05)$ and an increase of $\mathrm{N}-\mathrm{NH}_{3}$ concentration of $107.4 \%$. Unlike the microbial inoculants, no other effects on 
the fermentation products were observed by adding the by-product in the ensiling. Increments on $\mathrm{NH}_{3}$ and $\mathrm{pH}$ and no alterations in ethanol levels of sugarcane silages were observed when urea was added as an additive. These results probably occurred due to the urea hydrolysis to ammonia, the uptake of hydrogen ions and due to the fact that urea did not inhibit the growth of yeast and fungi (Castro Neto et al., 2008).

The addition of nitrogen sources (eg. urea and ammonium sulfate) in sugarcane silages to decrease ethanol production mainly by inhibiting yeast growth (BravoMartins et al., 2006) was expected, because the released ammonia would be toxic to those microorganisms (Alli et al., 1983). However, the results demonstrated a limited capacity of APB, at least at the tested level of addition, to improve the quality of the sugarcane silage when alcoholic fermentation occurs.

With regard the Pioneer and Mercosil inoculants, they markedly decreased the ethanol concentration, probably in response to the great production of acetic acid. Although Mercosil was already expected to increase the acetic acid concentration in view of the presence of the heterofermentative bacteria Lactobacillus buchneri, the effects of Pioneer are difficult to explain, since this inoculant did not provide those bacteria.

Pioneer and Mercosil increased $(\mathrm{P}<0.05)$ silage dry matter content in $14.0 \%$ and $16.3 \%$, respectively, when compared with the untreated silage (Table 3 ). This result is in agreement with the pronounced drop of ethanol concentrations in response to those inoculants. By decreasing the ethanol production, lower losses of volatile compounds will occur during the oven drying process of dry matter content determination, thereby increasing the silage DM content. Castro Neto et al. (2008) evaluated the inoculation of sugarcane silages with Lactobacillus plantarum (Biomax 5) and observed that there were no effects on DM and soluble carbohydrates contents, which partially concurs with the present results. In the study of Schneider et al. (1995), the inoculation of wet brewer grains silages with Lactobacillus plantarum and Streptococcus faecium did not have effects on DM, CP, NDF or ADF contents, but decreased soluble carbohydrates concentrations, which also partially agrees with the present findings. When Lactobacillus buchneri was inoculated in corn silage, it diminished soluble carbohydrates content, but it did not affect CP, NDF and ADF contents, whereas Lactobacillus plantarum (strains 30115, $1 \times 10^{6} \mathrm{cfu} / \mathrm{g}$ ) decreased NDF and ADF contents only (Ranjit \& Kung Jr., 2000). The inoculation of sugarcane silage with Lactobacillus buchneri did not affect the chemical composition, although it increased the weight gain and the feed conversion of heifers fed that silage (Pedroso et al., 2006), demonstrating that the inoculant can affect other quality parameters that determine the nutritional value of silages. These results suggest that the inoculant effects on the silage chemical composition depend on the type of forage ensiled and on the bacteria strains contained in the inoculant.

Mercosil also increased $(\mathrm{P}<0.05)$ the buffer capacity of silage in $15.6 \%$ when compared with control. This effect is compatible with the change that occurred in the fermentation profile, with the increment of acetic acid concentration and with the ethanol decline. Being a weak acid, the acetic acid influences the silage buffer capacity and its concentration using Mercosil was doubled in the present study, when compared with control. Another important observation was the $25.9 \%$ increase in IVDMD by using Pioneer as inoculant, which may benefit the animal performance by improving the nutrients availability and feed intake.

The addition of APB enhanced $(\mathrm{P}<0.05)$ the silage $\mathrm{CP}$ content in $49.7 \%$ and diminished $(\mathrm{P}<0.05)$ ADIN concentration in $38.7 \%$, compared with the untreated silage. This treatment also increased $(\mathrm{P}<0.05)$ the buffer capacity in $73.6 \%$, when compared with control. These effects can be

Table 3 - Chemical composition of sugarcane silages with additives

\begin{tabular}{|c|c|c|c|c|c|c|c|}
\hline \multirow[t]{2}{*}{ Item } & \multicolumn{5}{|c|}{ Treatment $^{1}$} & \multirow[b]{2}{*}{$\mathrm{CV}$} & \multirow[b]{2}{*}{$\operatorname{Pr}>F$} \\
\hline & Control & $\mathrm{APB}$ & Pioneer & Lalsil & Mercosil & & \\
\hline DM & $22.96 \mathrm{c}$ & $23.44 \mathrm{bc}$ & $26.18 \mathrm{ab}$ & $23.25 b c$ & $26.70 \mathrm{a}$ & 8.38 & 0.0031 \\
\hline $\mathrm{CP}$ & $3.54 b$ & $5.30 \mathrm{a}$ & $3.09 \mathrm{~b}$ & $3.46 b$ & $3.04 b$ & 24.15 & 0.0001 \\
\hline ADIN & $35.97 \mathrm{a}$ & $22.04 b$ & $37.31 \mathrm{a}$ & $37.64 \mathrm{a}$ & $40.46 a$ & 20.96 & 0.0001 \\
\hline $\mathrm{ADF}$ & $46.32 \mathrm{a}$ & $46.19 \mathrm{a}$ & $40.36 \mathrm{~b}$ & $45.65 \mathrm{ab}$ & $41.86 \mathrm{ab}$ & 7.83 & 0.0144 \\
\hline NDF & $68.58 \mathrm{a}$ & $69.12 \mathrm{a}$ & $61.13 b$ & $68.26 \mathrm{ab}$ & $62.47 \mathrm{ab}$ & 7.57 & 0.0437 \\
\hline $\mathrm{SC}$ & 9.76 & 10.46 & 8.14 & 9.40 & 13.35 & 31.91 & 0.2276 \\
\hline IVDMD & $40.62 b$ & $44.30 \mathrm{ab}$ & $51.16 \mathrm{a}$ & $46.26 \mathrm{ab}$ & $50.15 \mathrm{ab}$ & 12.48 & 0.0404 \\
\hline $\mathrm{BC}$ & $15.06 \mathrm{c}$ & $26.15 \mathrm{a}$ & $16.20 \mathrm{bc}$ & $15.11 \mathrm{c}$ & $17.41 \mathrm{~b}$ & 24.40 & 0.0001 \\
\hline
\end{tabular}

${ }^{1}$ Means in the same row followed by different letters differ by the Tukey test $(\mathrm{P}<0.05)$.

DM - dry matter (\%); CP - crude protein (\% DM); ADIN - acid detergent insoluble nitrogen (\% total N); ADF - acid detergent fiber (\% DM); NDF - neutral detergent fiber $(\% \mathrm{DM})$; SC - soluble carbohydrates (\% DM); IVDMD - in vitro dry matter digestibility (\% DM); BC - buffer capacity (meq./100 g DM); ABP - amino acid production byproduct; $\mathrm{CV}$ - coefficient of variation $(\%)$; $\mathrm{Pr}>\mathrm{F}$ - probability of type I error. 
explained by the APB composition, since the by-product is rich in proteins, amino acids and nitrogen as ammonium $\left(\mathrm{NH}_{4}{ }^{+}\right)$and these compounds contribute to the silage buffering. The decrease in ADIN concentration is probably due to a dilution effect when the fiber bound nitrogen is expressed as a ratio of the total nitrogen, which was notably greater in the APB treated silages (Table 1). Adding nitrogen sources to ensiling also enhanced the nutritional value of sorghum (Fernandes et al., 2009) and wet corn grain silages (Jobim et al., 2008). In a study with dairy heifers, adding urea to sugarcane silage which was included in a total mixed diet did not improve animal performance, which was justified by the production of indigestible nitrogen compounds (Pedroso et al., 2006). On the other hand, there were no effects of APB on the DM, ADF, NDF or SC contents, nor on IVDMD, in the present study.

With respect to treatment effects, Lalsil did not affect the aerobic stability of sugarcane silages (Table 4). Conversely, Pioneer and Mercosil presented desirable effects, because both inoculants increased in $93.7 \%$ and $112.8 \%$, respectively, the time the silage spent to reach the maximum temperature $(\mathrm{P}<0.05)$. This resulted in a decrease in the temperature increasing rate of $46.3 \%$ for Mercosil, although no effects were observed on either the maximum reached temperature or the time spent to increase temperature in $2^{\circ} \mathrm{C}$.

The APB did not affect the aerobic stability of sugarcane silage. This result is compatible with the limited capacity of APB to alter the fermentation patterns. Conversely, Pioneer and Mercosil inoculants notably improved the silage aerobic stability, which agrees with the fermentation results, as both additives increased the concentration of acetic acid and decreased the production of ethanol, probably due to the inhibition of yeast growth.

In corn silages, the inoculation of Lactobacillus plantarum enhanced the aerobic stability for 6 to 7 hours when compared with the untreated silage, whereas Lactobacillus buchneri was able to increase the aerobic stability for a period longer than 38 days, in response to an increment in acetic acid concentration, which was promoted by this inoculant (Ranjit \& Kung Jr., 2000). In wet corn grain silages, the addition of urea improved the aerobic stability and decreased dry matter losses, increasing the time needed to raise the silage temperature in $2^{\circ} \mathrm{C}$ and keeping the silage pH low (Jobim et al., 2008). In the present study, however, the additive effects were marginal.

Table 4 - Aerobic stability of sugarcane silages with additives

\begin{tabular}{|c|c|c|c|c|c|c|c|}
\hline \multirow[t]{2}{*}{ Item } & \multicolumn{5}{|c|}{ Treatment $^{1}$} & \multirow[b]{2}{*}{$\mathrm{CV}$} & \multirow[b]{2}{*}{$\operatorname{Pr}>F$} \\
\hline & Control & APB & Pioneer & Lalsil & Mercosil & & \\
\hline $\operatorname{MAXT}\left({ }^{\circ} \mathrm{C}\right)$ & $29.8 \mathrm{ab}$ & $28.4 b$ & $31.7 \mathrm{ab}$ & $32.9 \mathrm{a}$ & $30.5 \mathrm{ab}$ & 7.26 & 0.0203 \\
\hline TIR $\left({ }^{\circ} \mathrm{C} / \mathrm{h}\right)$ & $0.205 \mathrm{a}$ & $0.158 \mathrm{ab}$ & $0.133 \mathrm{ab}$ & $0.173 \mathrm{ab}$ & $0.110 \mathrm{~b}$ & 31.05 & 0.0330 \\
\hline TI2T (h) & 5.63 & 5.88 & 7.38 & 7.63 & 7.88 & 21.35 & 0.0853 \\
\hline
\end{tabular}

${ }^{1}$ Means in the same row followed by different letters differ $(\mathrm{P}<0.05)$ by Tukey test.

APB - amino acid production by-product; MAXT - maximum temperature reached $\left({ }^{\circ} \mathrm{C}\right)$; TIMAXT - time to reach maximum temperature (h); TIR - temperature increasing rate $\left({ }^{\circ} \mathrm{C} / \mathrm{h}\right)$; TI2T $(\mathrm{h})$ - time to increase $2{ }^{\circ} \mathrm{C} ; \mathrm{CV}$ - coefficient of variation (\%); Pr $>\mathrm{F}$ - probability of type I error.

\section{Conclusions}

In sugarcane silages under strong alcoholic fermentation, the by-product derived from amino acid production presents limited capacity to alter the fermentation parameters and the aerobic stability. The same can occur when heterofermentative bacteria are added to silage as the only inoculant. On the other hand, homofermentative bacteria can significantly increase the quality of the sugarcane silage.

\section{References}

ASSOCIATION OF OFFICIAL ANALYTICAL CHEMISTTS AOAC. Official methods of analysis. 10.ed. Washington, D.C.: $1980.1015 p$.
ALLI, I.; BAKER, B.; GARCIA, G. Studies on the fermentation of chopped sugarcane. Animal Feed Science and Technology, v.7, p.411-417, 1982.

ALLI, I.; FAIRBAIRN, R.; BAKER, B. et al. The effects of ammonia on the fermentation of chopped sugarcane. Animal Feed Science and Technology, v.9, p.291-299, 1983.

BRAVO-MARTINS, C.E.C.; CARNEIRO, H.; CASTRO-GÓMEZ, R.J.H. et al. Chemical and microbiological evaluation of ensiled sugarcane with different additives. Brazilian Journal of Microbiology, v.37, p.499-504, 2006.

CASTRO NETO, A.G.; MOLINA, L.R.; GONÇALVES, L.C. et al. Parâmetros de fermentação de silagens de cana-de-açúcar submetidas a diferentes tratamentos. Arquivo Brasileiro de Medicina Veterinária e Zootecnia, v.60, n.5, p.1150-1156, 2008.

DING, M-Y.; KOIZUMI, H.; SUZUKI, Y. Comparison of three chromatographic systems for determination of organic acids in wine. Analytical Sciences, v.2, p.239-243, 1995.

ELFERINK, S.J.W.H.O.; KROONEMAN, J.; GOTTSCHAL, J.C. et al. Anaerobic conversion of lactic acid to acetic acid and 1,2propanediol by Lactobacillus buchneri. Applied and Environmental Microbiology, v.67, p.125-132, 2001. 
ERWIN, E.S.; MARCO, G.J.; EMERY, E.M. Volatile fatty acid analyses of blood and rumen fluid by gas chromatography. Journal of Dairy Science, v.44, p.1768-1771, 1961.

FERNANDES, F.E.P.; GARCIA, R.; PIRES, A.J.V. et al. Ensilagem de sorgo forrageiro com adição de uréia em dois períodos de armazenamento. Revista Brasileira de Zootecnia, v.38, n.11, p.2111-2115, 2009.

FOLDAGER, J. Protein requeriment and non protein nitrogen for high producing cow in early lactation. 1977. $167 \mathrm{f}$. Thesis (PhD in Animal Science) - Michigan State University, East Lasing.

JOBIM, C.C.; LOMBARDI, L.; MACEDO, F.A.F. et al. Silagens de grãos de milho puro e com adição de grãos de soja, de girassol ou uréia. Pesquisa Agropecuária Brasileira, v.43, n.5, p.649-656, 2008.

JOHNSON, R.R.; BALWANI, T.L.; JOHNSON, L.J. et al. Corn plant maturity. II Effect on in vitro cellulose digestibility and soluble carabohydrate content. Journal of Animal Science, v.25, p.617-623, 1966.

KULASEK, G. A micromethod for determination of urea in plasma, whole blood and blood cells using urease and phenol reagent. Polskie Archiwum Weterynaryjne, v.15, n.4, p.801-10, 1972.

KUNG JR., L.; TUNG, R.S.; MACIOROWSKI, K. Effect of a microbial inoculant and/or glycopeptide antibiotic on fermentation and aerobic stability of wilted alfalfa silage. Animal Feed Science Technology, v.35, p.37-48, 1991 .

MACITELLI, F.; BERCHIELLI, T.T.; ANDRADE, P. et al. Influência do resíduo da produção do glutamato monossódico (Amiferm) sobre os parâmetros ruminais e o consumo de bovinos alimentados com silagem de milho. Archivo Latinoamericano de Producción Animal, v.11, n.2, p.111-118, 2003.

MOON, N. Inhibition of the growth of acid tolerant yeasts by acetate, lactate and propionate and their synergistic mixtures. Journal of Applied Bacteriology, v.55, p.453-460, 1983.

NIKU-PAAVOLA, M.-L.; LAITILA, A.; MATTILA-SANDHOLM, T. et al. New types of antimicrobial compounds produced by
Lactobacillus plantarum. Journal of Applied Microbiology, v.86, p.29-35, 1999 .

PEDROSO, A.F.; NUSSIO, L.G.; BARIONI JÚNIOR, W. et al Performance of Holstein heifers fed sugarcane silages treated with urea, sodium benzoate or Lactobacillus buchneri. Pesquisa Agropecuária Brasileira, v.41, n.4, p.649-654, 2006.

RANJIT, N.K.; KUNG JR., L. The effect of Lactobacillus buchneri, Lactobacillus plantarum, or a chemical preservative on the fermentation and aerobic stability of corn silage. Journal Dairy Science, v.83, p.526-535, 2000.

RUPPEL, K.A.; PITT, R.E.; CHASE, L.E. et al. Bunker silo management and its relationship to forage preservation on dairy farms. Journal of Dairy Science, v.78, n.1, p.141-153, 1995.

SCHNEIDER, R.M.; HARRISON, J.H.; LONEY, K.A. The effects of bacterial inoculants, beet pulp, and propionic acid on ensiled wet brewers grains. Journal of Dairy Science, v.78, p.1096-1105, 1995.

TILLEY, J.M.A.; TERRY, R.A. A two-stage technique for the in vitro digestion of forage crops. Journal of British Grassland Society, v.18, n.2, p.104-111, 1963.

WEINBERG, Z.G.; ASHBELL, G.; HEN, Y. et al. The effect of applying lactic acid bacteria on the aerobic stability of silages. Journal of Applied Bacteriology, v.75, p.512-518, 1993.

WEINBERG, Z.G.; MUCK, R.E. New trends and opportunities in the development and use of inoculants for silage. FEMS Microbiology Reviews, v.19, p.53-68, 1996.

VAN SOEST, P.J.; ROBERTSON, J.B. Analysis of forages and fibrous foods. Cornell University, 1985. 202p.

VAN SOEST, P.J.; ROBERTSON, J.B.; LEWIS, B.A. Symposium: Carbohydrate methodology, metabolism, and nutritional implications in dairy cattle. Methods for dietary fiber, neutral detergent fiber, and nonstarch polysaccharides in relation to animal nutrition. Journal of Dairy Science, v.74, n.1, p.3583-3597, 1991. 